\title{
DIALEKTIKA KOMUNIKASI, ISLAM, DAN BUDAYA SUNDA
}

\author{
Ujang Saefullah \\ Universitas Islam Negeri Sunan Gunung Djati Bandung \\ J1. AH Nasution No. 105 Bandung, Jawa Barat - 40600 \\ Telp.(022) 7810788, HP 081312255522 \\ email: us.saefullah@gmail.com \\ Naskah diterima tanggal 29 Mei 2013, disetujui pada tanggal 24 Juni 2013
}

\section{COMMUNICATION DIALECTICS, ISLAM, AND SUNDANESE CULTURE}

\begin{abstract}
Customary societies of Kampung Dukuh is community tightly maintaining their tradition up to the present. It appeared on their life routine beginning from the way of having intercourse, the custom of consuming, the kind of living, the system of leadership until the construction model of stage house constructed from bamboo with palm fiber for the roof. This study aimed to analyze: 1) language dialectic, communication and Sundanese culture at customary society of Kampung Dukuh 2) communication dialectic and tradition of Islam at customary society of Kampung Dukuh 3) Dialectic of Islam tradition and Sundanese culture at customary society of Kampung Dukuh. The method of this research is Ethnography of Communication with qualitative approach. The techniques of data collection are profound interview, participatory observation and documentation research. The results are 1) communication dialectic Sundanese culture lasted in total dialectic manner and indicated relation of dependence each other 2) communication dialectic and tradition of Islam prevailed in total dialectic way, and possessed dependence, affirmed as well as strengthen each other 3) tradition dialectic of Islam and Sundanese culture were divided into two categories namely 1) dialectic of Islam value and culture norm run in total dialectic manner and owned dependence each other 2) dialectic of Islam faith and myths lasted in contradictory way or be in conflict among two different extremes.
\end{abstract}

Keywords: dialectic, communication, Islam, Sundanese culture.

\begin{abstract}
Abstrak
Masyarakat Adat Kampung Dukuh adalah masyarakat yang masih sangat tradisional, hal ini tampak pada pola hidup mereka sehari-hari. Mulai dari pola pergaulannya, pola makannya, pola mata pencahariannya, pola kepemimpinannya sampai kepada model bangunan rumahnya yang panggung terbuat dari bambu beratapkan injuk. Penelitian ini bertujuan untuk menganalisis: (1) Dialektika bahasa, komunikasi dan budaya Sunda pada masyarakat Adat Kampung Dukuh, (2) Dialektika komunikasi dan tradisi Islam pada masyarakat Adat Kampung Dukuh, dan (3) Dialektika tradisi Islam dan budaya Sunda pada masyarakat Adat Kampung Dukuh. Metode yang digunakan adalah metode Etnografi Komunikasi dengan pendekatan kualitatif. Sedangkan teknik pengumpulan datanya adalah teknik wawancara mendalam, observasi partisipatorif, dan penelaahan dokumentasi. Hasil penelitian menunjukkan: (1) Dialektika komunikasi dan budaya Sunda berlangsung secara dialektis totality saling ketergantungan satu dengan yang lainnya, (2) Dialektika komunikasi dan tradisi Islam berjalan secara dialektika totality memiliki ketergantungan saling menguatkan dan meneguhkan. (3) Dialektika tradisi Islam dan budaya
\end{abstract}


Sunda terbagi ke dalam dua katagori, pertama, dialektika nilai Islam dan norma budaya berlangsung secara dialektika totality saling ketergantungan, dan kedua, dialektika aqidah Islam dan mitos-mitos terjadi secara kontradiktif atau bertentangan dari dua ekstrim yang berbeda.

Kata kunci : dialektika komunikasi, Islam, budaya Sunda.

\section{PENDAHULUAN}

Masyarakat Kampung Dukuh adalah masyarakat yang masih sangat tradisional, hal ini tampak pada pola hidup mereka seharihari. Mulai dari pola pergaulannya, pola makannya, pola mata pencahariannya, pola kepemimpinannya sampai kepada model bangunan rumahnya. Pola pergaulan masyarakat Kampung Dukuh masih sangat kental dengan tradisi gotong royong, tolong menolong, dan saling menghormati antarsesama, yang masih muda senantiasa menghormati yang lebih tua, yang tua menyayangi yang lebih muda. Begitupula suasana gotong royong pada masyarakat Kampung Dukuh masih terus dilestarikan. Kemudian pola makan masyarakat Kampung Dukuh masih sangat tradisional, mulai cara masaknya masih menggunakan "hawu" (tungku tempat masak terbuat dari tanah liat) dan "suluh" (kayu bakar), perkakas makannya, piring terbuat dari batok kelapa, dan gelas terbuat dari bambu, walaupun saat ini sudah ada yang menggunakan piring dan gelas dari kaca, tetapi mayoritas masih menggunakan piring dan gelas tradisional.

Sedangkan model bangunan rumahnya masih sangat asri mempertahankan model, "rumah adat" yaitu, "rumah panggung dari bambu yang beratapkan injuk". Bangunan tersebut sangat unik dan khas sebagai sebuah perkampungan yang jauh dari keramaian kota. Sementara pola kepemimpinannya menerapkan sistem dinasti atau keturunan, artinya seorang Ketua Adat (kuncen) harus berasal dari keturunan Embah Dukuh, dan Ketua Adat sekarang bernama, "Mama Uluk" keturunan Embah Dukuh ke 14, kecuali kalau tidak ada keturunan dari Embah Dukuh, baru boleh dari keluarga orang lain yang dianggap layak memegang tampuk kepemimpinan Kampung Dukuh.

Kampung Dukuh merupakan sebuah kampung yang terletak di kawasan desa Cijambe, kecamatan Cikelet, Kabupaten Garut. Jarak Kampung Dukuh ke kecamatan Cikelet kurang lebih $9 \mathrm{~km}$, sedangkan dari pusat kota relatif sangat jauh kurang lebih 101 km (Susanto, 2013). Kampung Dukuh merupakan salah satu perkampungan tradisional (kampung adat) yang masih kental menganut kepercayaan terhadap leluhurnya (nenek moyang), tetapi juga memegang tradisi keislaman yang sangat kuat. Kepercayaan terhadap leluhur (nenek moyang) yang dimaksud adalah nasihatnasihat dan pantangan-pantangan yang boleh dan tidak boleh dilakukan. Nasihat nenek moyang mereka adalah nasihat dari Embah Dukuh kepada generasi berikutnya, $k u d u$ hirup rukun, damai, dan tentram, serta harus amanah jadi pemimpin. Embah Dukuh juga melarang hidup mewah, sombong, dan serakah, bahkan ada pantangan-pantangan yang tidak boleh dilakukan oleh masyarakat Kampung Dukuh, yaitu, "ulah nyanghunjar ka kaler-makam" (jangan menjulurkan kaki ke arah makam), "ulah pipis nyanghareup $k a$ makam" (jangan kencing menghadap ke arah makam) dan, "ngaludah sambarangan" (meludah sembarangan).

Walaupun masyarakat adat Kampung Dukuh sangat kental memegang tradisi nenek moyangnya, tetapi mereka juga sangat taat menjalankan syariat agamanya, dalam hal ini ajaran Islam. Tradisi keislaman mereka sangat kental, fenomena tersebut tampak ketika datang panggilan salat lima waktu, seperti: zuhur, asar, Magrib, Isya, dan Subuh, para orang tua dan anak-anak ramai mengikuti salat berjamaah. Setelah salat berjamaah zuhur, Magrib, dan Subuh, anak-anak langsung mengikuti pengajian yang dibimbing oleh ustaz dan ustazah setempat. Kemudian dilaksanakan pengajian rutin kaum ibu setiap hari Selasa dan hari Jumat sore, sementara pengajian bapak-bapak 
dilaksanakan pada setiap menjelang salat Jumat. Ada juga pengajian setiap hari Jumat di rumah Mama Uluk (ketua adat) dengan mendawamkan membaca salawatan kamilah. Sebagaimana yang diungkapkan, $\mathrm{AH}$, bahwa: "Alhamdulillah masyarakat di dieu mah (Kampung Dukuh) anak-anaknya rame mengikuti pengajian Alquran setiap hari dalam tiga waktu yaitu bada salat zuhur, magrib dan bada salat subuh. Mereka dibimbing oleh para ustaz dan ustazah setempat. Bahkan untuk ibu-ibu juga diadakan setiap hari Selasa dan Jumat, untuk mendengarkan nasihat mama dan membaca salawat. Khusus untuk hari Jumat selalu di rumah Mama Uluk (kuncen) dengan membaca salawat kamilah dan doa-doa. Kemudian untuk pengajian bapak-bapaknya dilaksanakan menjelang salat Jumat, biasanya nasihat tentang ibadah dan akhlak" (wawancara dengan AH, 15 Maret 2013).

Ketaatan dalam menjalankan syariat agama Islam, diduga kuat merupakan pengaruh dari pendiri Kampung Dukuh yaitu Syekh K.H. Abdul Jalil dalam menanamkan ajaran Islam kepada murid-muridnya. Islam yang diajarkan Abdul Jalil adalah beraliran Mazab Syafei yang menjelma menjadi paham ahli sunnah waljamaah. Abdul Jalil sebagai seorang ulama seperti halnya ulama-ulama lain di Nusantara mengajarkan ajaran Islam mulai cara membaca Alquran dan memahami kandungannya, tauhid untuk mengenal Allah, cara beribadah, seperti: berwudu, salat, puasa, sampai kepada ajaran tasawuf. Ajaran itu membekas dari generasi ke generasi berikutnya sampai sekarang, sehingga suasana keberagamaan masyarakat Kampung Dukuh tampak dalam kehidupan sehari-hari.

Demikian pula, masyarakat Kampung Dukuh masih sangat kuat mempertahankan bahasa dan seni Sundanya. Bahasa yang digunakan sehari-hari adalah bahasa Sunda. Bahasa Sunda sebagai alat komunikasi masyarakat Kampung Dukuh yang digunakan dalam berbagai aktivitas sehari-hari, baik dalam pergaulan, pertemuan warga, pengajian anak-anak, ibu-ibu, dan bapak-bapak, termasuk pada ritual-ritual keagamaan, pernikahan, kelahiran, kematian, dan lainlain. Sedangkan seni Sunda yang dilestarikan masyarakat Kampung Dukuh adalah kesenian asli yang berasal dari Kampung Dukuh sendiri, salah satunya adalah seni, "Terbang Sejak" dengan karakteristik yang unik dan menarik.

Uraian di atas, menunjukkan bahwa masyarakat Kampung Dukuh relatif masih sangat kuat melestarikan budaya asli yang diwariskan oleh nenek moyangnya secara turun temurun dari generasi yang satu ke generasi berikutnya sampai saat ini. Sehingga fenomena tersebut menarik untuk diteliti. Masalah yang diangkat dalam penelitian ini adalah bagaimana dialektika komunikasi, Islam, dan Budaya Sunda pada masyarakat adat Kampung Dukuh?

Penelitian ini bertujuan untuk menganalisis: (1) Dialektika bahasa, komunikasi, dan budaya Sunda pada masyarakat adat Kampung Dukuh; (2) Dialektika bahasa, komunikasi dan tradisi Islam pada masyarakat adat Kampung Dukuh; (3) Dialektika tradisi Islam dan budaya Sunda pada masyarakat adat Kampung Dukuh.

\section{LANDASAN KONSEP}

\section{Dialektika Komunikasi dan Budaya}

Konsep dasar dialektika komunikasi dan budaya, dapat dibaca melalui tulisan Martin dan Nakayama dalam Ekajati (1984), yang menjelaskan bahwa dialektika komunikasi dan budaya sesungguhnya memberi suatu pemahaman bertingkat. Dengan demikian tidak ada bentuk dialektika tunggal yang sempurna secara epistemologis dalam kompleksitas budaya. Martin dan Nakayama selanjutnya, mengatakan bahwa perspektif dialektika terjadi saling ketergantungan dalam interaksi antarbudaya (Sugito, 2010). Hal tersebut sangat penting dalam memahami dialektika komunikasi dan budaya, termasuk masalah penelitian yang diangkat penulis yaitu, dialektika komunikasi, Islam, dan budaya Sunda pada masyarakat adat Kampung Dukuh.

Berikutnya Martin dan Nakayama 
memandang, bahwa perspektif dialektika budaya dan komunikasi memiliki beberapa tingkatan, yaitu:

1. Dialektika Individu-Budaya (CulturalIndividual Dialectic). Dialektika individuindividu tersebut dapat terjadi pada proses komunikasi antarbudaya. Komunikasi antarbudaya dari perspektif dialektika bersifat individu dan budaya;

2. Dialektika Personal/Sosial-Kontekstual (Personal/Social-Contecstual Dialectic). Perspektif dialektika ini melihat hubungan antara personal dan kontekstual dari komunikasi. Manusia berkomunikasi dengan cara tertentu dan dalam konteks tertentu pula;

3. Dialektika Kesamaan-Perbedaan (Differences-Similarities Dialectic). Dialektika kesamaan dan perbedaan ini sangat esensial dalam memahami komunikasi antarbudaya. Kesamaanperbedaan ini menjadi penting dalam memahami keberadaan kelompokkelompok budaya yang berbeda;

4. Dialektika Dinamik-Statik (StaticDynamic Dialectic). Perspektif dinamikstatik ini membantu untuk memahami dunia yang luas dan mengembangkan cara memahami antarbudaya itu sendiri;

5. Dialektika Sekarang-Masa Lalu/Masa Depan-Sejarah (Present-Future/HistoryPast Dialectic). Dialektika komunikasi antarbudaya berada di antara masa lalu, dan masa kini. Perspektif dialektika ini memberi gambaran tentang seharusnya ada keseimbangan dalam memahami masa kini dan masa lalu;

6. Dialektika Untung-Rugi (PrivilegeDisadvantage Dialectic). Perspektif dialektika ini memberikan gambaran bahwa orang melakukan komunikasi pada bentuk-bentuk yang menguntungkan dirinya atau tidak. Tindakan komunikasi seperti itu sering terjadi di dalam dunia politik, posisi sosial, dan kedudukan (Sugito, 2010).

\section{Etnografi Komunikasi}

$\begin{array}{ccr}\text { Hymes } & \text { mengatakan } & \text { Etnografi } \\ \text { Komunikasi } & \text { (Ethnography } & \text { of }\end{array}$

Communication) merupakan pengembangan dari etnografi berbicara (Ethnography of Speaking) (Kuswarno, 2008). Pengkajian Etnografi Komunikasi ditujukan pada kajian peranan bahasa dalam perilaku komunikatif suatu masyarakat, yaitu mengenai cara-cara bagaimana bahasa dipergunakan dalam masyarakat yang berbeda-beda kebudayaannya.

Syukur dalam Kuswarno (2008), Etnografi Komunikasi sebagai pendekatan terhadap sosiolinguistik bahasa, yaitu melihat penggunaan bahasa secara umum dihubungkan dengan nilai-nilai sosial dan kultural. Sehingga tujuan deskripsi Etnografi adalah untuk memberikan pemahaman global mengenai pandangan dan nilai-nilai suatu masyarakat sebagai cara untuk menjelaskan sikap dan perilaku anggota-anggotanya. Syukur dalam Kuswarno (2008), dengan kata lain, Etnografi Komunikasi menggabungkan penggunaan sosiologi (analisis interaksional dan identitas peran) dengan antropologi (kebiasaan penggunaan bahasa dan filosofi yang melatarbelakangi) dalam konteks komunikasi, atau ketika bahasa itu dipertukarkan.

Hymnes dalam Kuswarno (2008) menjelaskan ruang lingkup kajian Etnografi Komunikasi adalah sebagai berikut:

1. Pola dan fungsi komunikasi (patterns and functions of communication);

2. Hakikat dan definisi masyarakat tutur (Inature and definition of speech);

3. Cara-cara berkomunikasi (means of communicating);

4. Komponen-komponen kompetensi komunikatif (components of communicative competence);

5. Hubungan bahasa dengan pandangan dunia dan organisasi sosial (relationship of language to world view and social organization);

6. Semesta dan ketidaksamaan linguistik dan sosial (linguistic and social universals and inqualities).

Dalam membahas ruang lingkup kajian, terlebih dahulu dipaparkan dua unsur dari Etnografi Komunikasi, yakni: particularistic, yaitu menjelaskan dan memahami perilaku komunikasi dalam 
kebudayaan tertentu. Sehingga sifat penjelasannya terbatas pada satu konteks tempat dan waktu tertentu. Generalizing, yaitu memformulasikan konsep-konsep dan teori untuk kebutuhan pengembangan meta teori global komunikasi antarmanusia.

\section{Islam dan Budaya Sunda}

Islam adalah agama yang diturunkan oleh Allah SWT kepada Rasul terakhir Muhammad SAW, melalui malaikat Jibril untuk disampaikan kepada umatnya agar mencapai kebahagiaan di dunia dan akhirat. Lebih jelas, Ambary (1997) menjelaskan bahwa Islam adalah agama samawi (langit) yang diturunkan oleh Allah SWT yang ajaranajaran-Nya terdapat dalam kitab suci Alquran dan Sunnah dalam bentuk perintah-perintah, larangan-larangan, dan petunjuk-petunjuk untuk kebaikan manusia, baik di dunia maupun di akhirat.

Sedangkan budaya Sunda atau kebudayaan Sunda merupakan manisfestasi gagasan dan pikiran serta kegiatan, baik yang abstrak maupun yang berbentuk bendawi, sekelompok manusia yang disebut atau menamakan dirinya sebagai orang Sunda (Rosyidi, 2004). Orang Sunda adalah orangorang yang tinggal terutama di wilayah barat pulau Jawa yang disebut sebagai Provinsi Jawa Barat (kecuali orang Jawa Cirebon dan Jawa Banten yang menghuni pantai utara Cirebon dan Banten, dan orang Melayu Betawi yang tinggal di Jakarta dan sekitarnya) (Rosyidi, 2004). Jadi wilayah Jawa Barat itu, menurut Jati (1984) bahwa berdasarkan penemuan benda-benda prasejarah yang tersebar dari pesisir utara (yang sekarang termasuk daerah Kabupaten Tangerang, Bekasi, dan Karawang), kampung Muara dan Pasirangin (sekarang termasuk Kabupaten Bogor), Lembah Leles (Kabupaten Garut sampai ke Cipari Kuningan), telah terdapat kehidupan bermasyarakat yang teratur. Berbagai alat sehari-hari, baik untuk keperluan hidup atau mencari nafkah maupun untuk keperluan upacara keagamaan, menjadi bukti yang menunjukkan bahwa sejak ribuan tahun wilayah tersebut telah dihuni oleh manusia yang telah mengenal kehidupan bermasyarakat yang terorganisasi. Itulah yang disebut orang-orang/manusia-manusia Sunda.

Hubungan Islam dengan budaya Sunda berlangsung sejak ratusan bahkan ribuan tahun yang lalu. Menurut Hidayat (2008) agama Islam masuk ke Tatar Sunda melalui tiga pelabuhan besar yaitu Cirebon, Jayakarta, dan Banten yang semuanya itu merupakan tiga pusat kekuasaan dan perdagangan di Jawa Barat waktu itu. Melalui ketiga pusat kekuasaan itu tiga kerajaan pedalaman di tatar Sunda yaitu Pajajaran, Sumedang Larang, dan Galuh ditundukkan dan kemudian masyarakatnya dengan cepat beralih agama dari Hindu-Buddha ke Islam. Orang Sunda lebih gampang menyatu dengan Islam dibanding dengan orang Jawa karena agama Hindu-Buddha orang Sunda sangat tipis. Bahkan, agama mereka yang sebenarnya adalah agama Karuhun yang gampang berintegrasi dan berasimilasi dengan Islam. Akhirnya, Islam menjadi identitas utama orang Sunda di samping kesundaan.

Secara teologis, keislaman orang Sunda sama saja dengan yang dianut oleh penduduk Nusantara. Islam yang datang ke sini dan yang akhirnya sangat dominan adalah Islam yang fiqihnya adalah Syafiiyah, aqidahnya adalah Asyariyah, dan tasawufnya adalah tasawufnya Sunni yang aneka ragam. Akan tetapi dari sudut pengembangan budaya, Islam yang diserap dan jadi agama masyarakat adalah Islam yang tidak atau kurang memberi dorongan bagi kemajuan kebudayaan. Kemudian secara sosiologis, masyarakat Sunda sudah dibangun sesuai dengan aspek tertentu dari sistem masyarakat Islam, dalam arti hubungan antara individu dan kegiatan masyarakat banyak berdasarkan prinsip Islam. Hal itu tercermin, misalnya, dalam peribahasa yang jadi filsafat Sunda , yaitu "silih asah, silih asih, dan silih asuh." (Hidayat, 2008).

\section{Kerangka Teori}

Paradigma yang dibangun dalam penelitian ini adalah Dialektika Komunikasi, Islam, dan Budaya Sunda di masyarakat Adat Kampung Dukuh Garut. Untuk membahas masalah tersebut dapat dijelaskan melalui 
teori Etnografi dan teori Dialektika Relasional. Kedua teori tersebut dapat dikemukakan sebagai berikut:

\section{Teori Etnografi}

Studi Etnografi Komunikasi adalah pengembangan dari antropologi linguistik yang dipahami dalam konteks komunikasi. Studi ini diperkenalkan pertama kali oleh Dell Hymes pada tahun 1962, sebagai kritik terhadap ilmu linguistik yang terlalu memfokuskan diri pada fisik bahasa saja. Definisi Etnografi Komunikasi itu sendiri adalah pengkajian peranan bahasa dalam perilaku komunikatif suatu masyarakat, yaitu cara-cara bagaimana bahasa dipergunakan dalam masyarakat yang berbeda-beda kebudayaannya (Kuswarno, 2008).

Lindlof dan Taylor, dalam bukunya Qualitative Communication Research Methods. Menyatakan "Ethnography of communication (EOC) conceptualizes communication as a continous flow of information, rather than as segmented exchanges message" (Lindlof dan Taylor, 2002). Dalam pernyataan tersebut, Lindlof dan Taylor menegaskan bahwa konsep komunikasi dalam Etnografi Komunikasi merupakan arus informasi yang berkesinambungan, bukan sekedar pertukaran pesan antarkomponennya semata.

Jadi etnografi lazimnya bertujuan menguraikan suatu budaya secara menyeluruh, yakni semua aspek budaya, baik yang material seperti artefak budaya (alatalat, pakaian, bangunan, dan sebagainya) dan yang bersifat abstrak, seperti pengalaman, kepercayaan, norma dan sistem nilai kelompok yang diteliti. Uraian tebal (thick description) merupakan ciri utama etnografi (Mulyana, 2003).

\section{Dialektika Relasional}

Teori Dialektika Relasional menggambarkan hidup hubungan sebagai kemajuan dan pergerakan yang konstan. Orang-orang yang terlibat di dalam hubungan terus merasakan dorongan dan tarikan dari keinginan-keinginan yang bertolak belakang di dalam sebuah bagian hidup berhubungan.
Pada dasarnya, orang menginginkan baik/maupun (both/and) dan bukannya hanya/atau (either/or) ketika membicarakan dua tujuan yang berlawanan. Ketika orang berkomunikasi di dalam hubungan mereka, mereka berusaha untuk mendamaikan keinginan-keinginan yang saling bertolak belakang ini, tetapi mereka tidak pernah menghapuskan kebutuhan mereka akan kedua bagian yang saling bertolak belakang ini (Adriyanto, 2010).

Asumsi dasar Teori Dialektika Relasional, sebagai berikut:

- Hubungan tidak bersifat linier. Asumsi ini berpendapat hubungan manusia terdiri atas fluktuasi yang terjadi antara keinginan-keinginan yang kontradiktif.

- Hidup berhubungan ditandai dengan adanya perubahan. Proses atau perubahan suatu hubungan merujuk pada pergerakan kuantitatif dan kualitatif sejalan dengan waktu dan kontraksi-kontraksi yang terjadi, di seputar mana suatu hubungan dikelola (Baxter dan Montgomery, 1996).

- Kontradiksi merupakan fakta fundamental dalam hidup berhubungan. Kontradiksi atau ketegangan terjadi antara dua hal yang berlawanan tidak pernah hilang dan tidak pernah berhenti menciptakan ketegangan.

- Komunikasi sangat penting dalam mengelola dan menegosiasikan kontradiksi-kontradiksi dalam hubungan. Dalam perspektif Dialektika Relasional, aktor-aktor sosial memberikan kahidupan melalui praktik-praktik komunikasi mereka kepada kontradiksi-kontradiksi yang mengelola hubungan mereka (Adriyanto, 2010).

Elemen-elemen dasar dalam perspektif dialektis, yaitu:

1. Totalitas (totality), mengakui adanya saling ketergantungan antara orang-orang dalam sebuah hubungan;

2. Kontradiksi (contradiction), merujuk pada oposisi - dua elemen yang bertentangan;

3. Pergerakan (motion), merujuk pada sifat berproses dan hubungan dan perubahan yang terjadi pada hubungan itu seiring dengan berjalannya waktu; 
4. Praksis (praxis), merujuk pada kapasitas manusia sebagai pembuat pilihan.

Selanjutnya Dialektika Relasi Dasar dapat dikategorikan ke dalam dua kategori yakni (a) dialektika interaksi (interactional dialectics), (b) dialektika kontekstual (contextual dialectics) dialektika interaksi (interactional dialectics) terdiri atas:

1. Otonomi dan keterikatan (autonomy and connections), merujuk pada sebuah ketegangan hubungan yang penting yang menunjukkan keinginan-keinginan kita yang saling berkonflik untuk menjadi dekat maupun jauh;

2. Keterbukaan dan perlindungan (openness and protection), merujuk pada ketegangan dalam berhubungan yang penting yang menunjukkan keinginan-keinginan kita yang saling berkonflik untuk mengatakan rahasia kita dan untuk menyimpannya;

3. Hal yang baru dan hal yang dapat diprediksi (novelty and predictability), merujuk pada ketegangan dalam berhubungan yang penting yang menunjukkan keinginan-keinginan kita yang saling berkonflik untuk memiliki stabilitas dan perubahan (Adriyanto, 2010).

Sedangkan dialektika kontekstual (contextual dialectics) dapat diuraikan sebagai berikut:

1. Dialektika publik dan privat (publik and private dialectics), merujuk pada ketegangan-ketegangan antara hubungan privat dan kehidupan publik;

2. Dialektika yang nyata dan real (real and ideal dialectics), merujuk pada ketegangan-ketegangan yang muncul dari perbedaan antara hubungan yang dianggap ideal dengan hubungan yang dijalani (Adriyanto, 2010).

Berdasarkan konsep dan teori di atas, maka kerangka teori dapat divisualisasikan sebagai berikut:

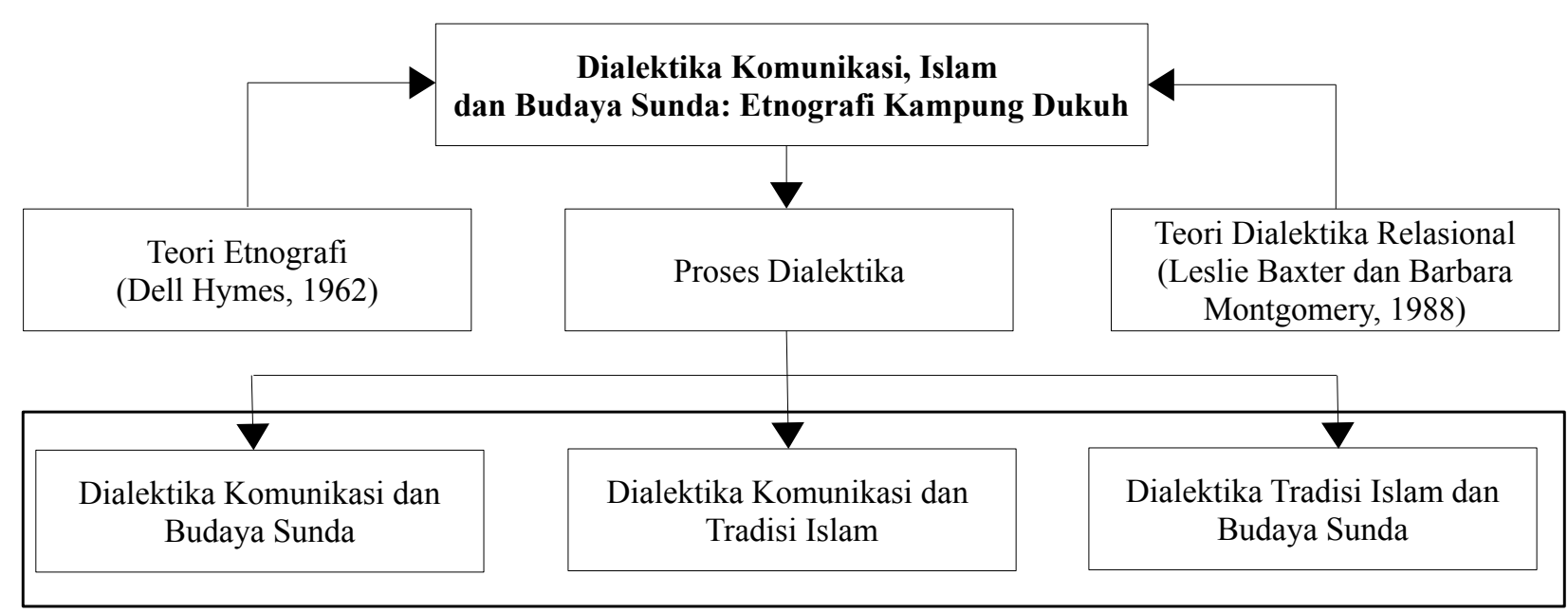

Sumber: Konstruksi Penulis 2013

Gambar 1

Bagan Kerangka Teori 


\section{METODE PENELITIAN}

Metode yang digunakan dalam penelitian ini adalah metode Etnografi Komunikasi yaitu metode yang khusus secara ilmiah menjelaskan tentang bahasa, komunikasi, dan kebudayaan dalam suatu konteks dan pada satu kelompok masyarakat tertentu, dalam hal ini masyarakat adat Kampung Dukuh. Kuswarno (2008) menjelaskan bahwa Etnografi Komunikasi tidak hanya membahas kaitan antara bahasa dan komunikasinya saja, atau kaitan antara bahasa dan kebudayaan, melainkan membahas ketiganya secara sekaligus. Sedangkan pendekatan yang digunakan adalah pendekatan kualitatif. Penulis merupakan instrumen pengumpul data dan kemudian data dianalisis secara induktif lalu proses yang diteliti dijelaskan secara ekspresif. Adapun teknik pengumpulan data yang digunakan adalah: 1) wawancara mendalam: 2) observasi partisipatorif; 3) pengamatan langsung; dan 4) penelaah dokumentasi.

\section{HASIL PENELITIAN DAN PEMBAHASAN}

\section{Dialektika Komunikasi dan Budaya Sunda}

Dialektika komunikasi dan budaya terjadi dalam tiga tingkatan, yaitu: 1) dialektika dinamik-statik; 2) dialektika bahasa dan budaya Sunda; dan 3) dialektika keharusan dan Pamali.

\section{Dialektika Dinamik-Statik}

Perspektif dialektika ini menunjukkan adanya saling ketergantungan antara masyarakat yang statik dan menutup diri terhadap pengaruh-pengaruh modernisasi dari dunia luar, dengan masyarakat yang sudah dinamik dan terbuka dengan adanya pembaharuan. Kelompok masyarakat yang statis diwakili oleh para sesepuh atau orang tua yang masih kuat memegang tradisi nenek moyangnya. Kelompok ini menolak adanya listriknisasi, teknologi informasi, dan alat-alat elektronik sampai kepada perkakas rumah tangga, seperti kompor gas, magic com, magic jar, dan lan-lain. Mereka menolak kehadiran barang-barang tersebut, karena khawatir akan merusak tatanan adat istiadat masyarakat Kampung Dukuh. Konteks tersebut, sebagaimana yang diungkapkan oleh K A, bahwa:

"Bila barang-barang modern itu masuk ke Kampung Dukuh kemudian warga Dukuh memiliki barang-barang tersebut, maka masyarakat akan terkesan merasa mewah. Dengan perasaan mewah itu mereka akan menjadi sombong, sedangkan sombong dan pamer dilarang oleh para leluhur. Kalau itu terjadi maka tinggal menunggu waktu malapetaka akan menimpa masyarakat Dukuh, seperti yang pernah terjadi kebakaran di kampung ini gara-gara ada warga yang membawa barang-barang tadi" (wawancara dengan KA, 18 Maret 2013).

Penjelasan Abu tersebut, dapat diketahui bahwa sesungguhnya para sesepuh khawatir akan keberlangsungan adat Kampung Dukuh terkikis habis oleh pengaruh modernisasi yang datang dari kota, baik dalam bidang sosial budaya, ekonomi, politik, maupun seni-lokal dan sistem kepemimpinan. Dalam bidang sosial budaya mereka menentang adanya listrik dan barang-barang elektronik datang ke Kampung Dukuh. Kemudian mereka juga tidak setuju sistem perekonomian pertanian menggunakan traktor, tetapi cukup dengan alat tradisional, seperti cangkul dan kerbau untuk membajak sawah. Begitu pula dalam bidang politik mereka tidak mau terombang-ambing oleh polarisasi pertentangan politik seperti yang terjadi di kota, tetapi urusan politik menyerahkan sepenuhnya kepada petuah Ketua Adat (kuncen). Sedangkan kesenian lokal yang terus dipertahankan adalah kesenian Terbang Sejak yaitu seni pertunjukan yang dilakukan sekelompok orang berpakaian serba hitam (kampret) khas Sunda. Pertunjukan itu dimulai dengan melantunkan puji-pujian kepada Allah dengan diiringi alat musik Rebana Besar dan Dogdog dan menampilkan atraksi debus. Selanjutnya dalam urusan kepemimpinan mereka menerapkan sistem dinasti, artinya model 
kepemimpinan Adat Dukuh yang didasarkan pada sistem keturunan. Namun, sikap dan pendirian para sesepuh tidak semuanya berjalan mulus, karena sebagian anak mudanya menginginkan adanya perubahan dalam pola pikir, pola sikap, dan pola tindak, sehingga secara diam-diam mereka mulai menerima adanya telepon genggam/HP dan sebagian kecil ada yang sudah memilikinya, di antaranya KA dan AH. Tetapi HP hanya boleh digunakan untuk berkomunikasi saja dan tidak boleh ada suara dan musik. Kelompok pemuda inilah kelompok yang masuk kelompok dinamis (berkembang).

Kedua kelompok ini saling berinteraksi secara dialektis dari waktu ke waktu, kelompok statis tetap ingin mempertahankan adat istiadat secara ketat dan tanpa kompromi. Walaupun angin perubahan sangat terbuka karena seringnya datang wisatawan lokal dan asing, sedikit banyak sangat mengganggu adat istiadat mereka. Misalnya tamu yang datang sering membawa barang elektronika yang aneh-aneh seperti kamera, HP, dan lainlain. Sedangkan kelompok dinamis yang ingin menyesuaikan diri dengan perkembangan zaman, sudah mulai ada yang terpengaruh misalnya secara sembunyisembunyi sudah ada yang memiliki HP, walaupun HP tersebut hanya untuk berkomunikasi saja dan tidak boleh berbunyi. Di sinilah dialektika komunikasi berlangsung secara kontradiktif.

\section{Dialektika Bahasa dan Budaya Sunda}

Dialektika bahasa dan budaya berlangsung setiap saat. Bahasa sebagai bagian dari budaya, dan budaya bisa berkembang karena jasa bahasa. Bagaimana bahasa (khusus bahasa Sunda) sebagai alat komunikasi mayarakat Dukuh bekerja setiap waktu untuk melestarikan adat istiadat Kampung Dukuh. Adat istiadat atau budaya Kampung Dukuh tidak akan lestari tanpa bahasa, sebaliknya adat istiadat komunitas tertentu akan tetap eksis karena bahasa. Baik bahasa lisan maupun tulisan. Bahasa lisan adalah bahasa yang dikomunikaskan dari mulut ke mulut, seperti tentang sejarah lahirnya masyarakat Adat Kampung Dukuh beredar di masyarakat kebanyakan melalui bahasa lisan. Sedang bahasa tulisan yaitu transkrip-transkrip yang diwariskan secara turun temurun dari sesepuh adat terdahulu ke anak cucunya sampai kepada sesepuh adat yang sekarang Mama Uluk (2013). Transkrip itu saat ini berada di Mama Uluk sebagai panduan dalam melestarikan nasihat-nasihat Embah Dukuh kepada generasi berikutnya. Oleh karena itu bahasa memegang peranan penting dalam melestarikan sebuah entitas budaya, termasuk entitas Kampung Dukuh. Pelestarian budaya Kampung Dukuh dikomunikasikan dari satu generasi ke generasi berikutnya melalui bahasa.

Bahasa menurut Keraf (1997) sebagai alat komunikasi antara anggota masyarakat berupa simbol bunyi yang dihasilkan oleh alat ucap manusia. Masyarakat Kampung Dukuh berinteraksi satu dengan yang lainnya dengan menggunakan bahasa Sunda untuk mengidentifikasikan diri sebagai masyarakat Adat Dukuh yang khas. Di sini bahasa, komunikasi dan budaya saling berinteraksi secara dialektis, dalam setiap aktivitas masyarakat Dukuh, baik dalam pergaulan sehari-hari, kegiatan ekonomi pertanian, pelaksanaan ritual keagamaan maupun dalam acara kelahiran, kematian, perkawinan, dan kesenian.

Bila bahasa, komunikasi dan budaya saling berdialog secara dialektis, satu dengan yang lainnya saling membutuhkan, maka dialektika terjadi adalah totality artinya adanya saling ketergantungan, sebagaimana yang diungkapkan oleh Baxter dan Montgomery (1996) bahwa dialektika ini mengakui adanya saling ketergantungan antara orang-orang dalam sebuah hubungan. Di situlah makna Etnografi Komunikasi yang sesungguhnya. Sebagaimana yang dikemukakan oleh Hymes dalam Ibrahim. (1994) Etnografi Komunikasi (Ethnography of Communication) merupakan pengembangan dari Etnografi berbicara (Ethnography of Speaking). Jelasnya Etnografi Komunikasi membahas bahasa, komunikasi, dan kebudayaan dalam suatu konteks dan pada satu kelompok masyarakat tertentu. Sehingga, Kuswarno (2008) mengatakan, Etnografi Komunikasi tidak 
hanya membahas kaitan antara bahasa dan komunikasi saja, atau antara bahasa dan kebudayaan, melainkan membahas ketiganya secara sekaligus.

\section{Dialektika Kudu dan Pamali}

$K u d u$ dan Pamali merupakan nasihatnasihat para leluhur Kampung Dukuh mana yang harus dilakukan (perintah) dan mana yang tidak boleh dilakukan (larangan/pantangan). Perintah (kudu) dan pantangan (Pamali) sudah menjadi norma budaya yang mengikat bagi seluruh masyarakat Kampung Dukuh. Kudu dan Pamali terus berlangsung selama ratusan tahun yang lalu sejak berdirinya Kampung Dukuh pada abad 17 oleh Syekh Abdul Jalil dan dilanjutkan oleh Embah Dukuh secara turun temurun kepada generasi berikutnya sampai saat ini. Saat ini masyarakat Kampung Dukuh di bawah kepemimpinan Mama Uluk tetap memegang kuat nasihat-nasihat para leluhur tersebut. Kudu dan Pamali tersebut bersinggungan secara dialektik. Perspektif dialektik ini bersifat totality, sebagaimana yang diungkapkan oleh Baxter dan Montgomery (1996) bahwa dialektika ini mengakui adanya saling ketergantungan antara orang-orang dalam sebuah hubungan. Hubungan di antara warga Kampung Dukuh diikat oleh tradisi $k u d u$ dan Pamali tersebut. Nasihat $k u d u$ atau sesuatu yang harus dilakukan masyarakat Adat Dukuh, antara lain:

1. Ngahaturan tuang dan nyanggakeun (mempersilakan makan). Merupakan kegiatan yang dilakukan masyarakat Kampung Dukuh atau pengunjung yang berasal dari luar apabila memiliki keinginan-keinginan tertentu seperti kelancaran dalam usaha, perkawinan, jodoh, dengan memberikan bahan makanan seperti garam, kelapa, telur ayam, kambing, atau lainnya sesuai kemampuan. Nyanggakeun (mempersilakan) merupakan suatu kegiatan penyerahan sebagian hasil pertanian kepada kuncen untuk diberkahi. Masyarakat tidak diperbolehkan memakan hasil panennya sebelum melakukan kegiatan nyanggakeun;

2. Tilu Waktos (tiga waktu). Merupakan ritual yang dilakukan oleh kuncen yaitu dengan membawa makanan ke dalam Bumi Alit (Bumi Dalam) atau Bumi Lebet (Rumah Dalam) untuk tawasul. Kuncen membawa sebagian makanan ke Bumi Alit lalu berdoa. Biasa dilakukan pada hari raya 1 Syawal, 10 Rayagung, 12 Maulud, 10 Muharram;

3. Manuj merupakan penyerahan bahan makanan dari hasil bumi kepada kuncen untuk diberkati pada hari raya Idulfitri dan Iduladha untuk maksud perayaan/syukuran;

4. Moro merupakan kebiasaan untuk menyerahkan hasil-hasil bumi yang dimiliki kepada aparat pemerintah seperti lurah dan camat;

5. Cebor Opat Puluh (Menyiram 40) merupakan mandi dengan empat puluh kali siraman dengan air dengan air dari pancuran yang terdapat di jamban yang dicampur dengan air khusus yang telah diberi doa-doa (wawancara, 06 Juni 2012).

Sedangkan Pamali atau pantangan yang sudah menjadi norma adat Kampung Dukuh relatif sangat banyak, misalnya:

1. Tidak boleh menjulurkan kaki ke arah makam keramat baik di saat tidur maupun sedang duduk;

2. Tidak boleh buang air kecil atau besar dengan arah ke makam keramat kecuali dilakukan di jamban umum;

3. Tidak boleh buang air kecil/makan sambil berdiri;

4. Tidak boleh makan dengan menggunakan sendok atau garpu;

5. Tidak boleh menjual makanan yang telah dimasak;

6. Tidak boleh memiliki benda-benda elektronik seperti televisi, radio, tape recorder, dan lain-lain;

7. Tidak boleh menggunakan petromak atau jenis lampu lain yang menggunakan minyak tanah;

8. Tidak boleh memiliki kursi, lemari, ranjang, perhiasan, dan peralatan lain yang terkesan mewah; 
9. Tidak boleh menempel gambar apapun kecuali ayat-ayat Alquran;

10. Dilarang menumbuk padi pada hari Selasa dan Jumat;

11. Dilarang pergi ke kebun atau ke tempat lain yang letaknya jauh pada hari Jumat;

12. Tidak boleh bepergian pada saat larangan sasih atau kala ageung;

13. Tidak boleh melakukan apapun pada saat hari nahas yaitu hari meninggalnya orangtua;

14. Tidak boleh memasuki makam keramat pada sembarang waktu;

15. Tidak boleh memakai awalan "si" apabila memanggil atau menyebut nama seseorang;

16. Tidak boleh memadu kasih (pacaran) terlalu lama;

17. Tidak boleh menikah dengan orang yang beragama non-Islam;

18. Tidak boleh melanggar syara (syariat atau hukum Islam) (Muhammad, 2009). merupakan produk budaya yang dihasilkan oleh masyarakat adat Kampung Dukuh. Inilah yang disebut budaya atau kebudayaan. Karena kebudayaan, menurut Koentjaraningrat (2009) adalah hasil dari cipta, karsa, dan rasa (manusia). Kemudian Honigmann, melalui karyanya, The World of Man (Koentjaraningrat, 2009) membedakan adanya tiga gejala kebudayaan, yaitu (1) ideas, (2) activities, (3) artifacts. Sedangkan Koentjaraningrat (2009) sendiri, berpendirian bahwa kebudayaan itu, memiliki tiga wujud, yaitu: (1) Wujud kebudayaan sebagai suatu komplek dari ide, gagasan, nilai, norma, peraturan, dan sebagainya; (2) Wujud kebudayaan sebagai suatu komplek aktivitas serta tindakan berpola dari manusia dalam masyarakat; dan (3) Wujud kebudayaan sebagai benda-benda hasil karya manusia. Berdasarkan uraian di atas, maka model dialektika komunikasi dan budaya Sunda, dapat dilihat pada gambar 2

Kedua petuah sesepuh tersebut,

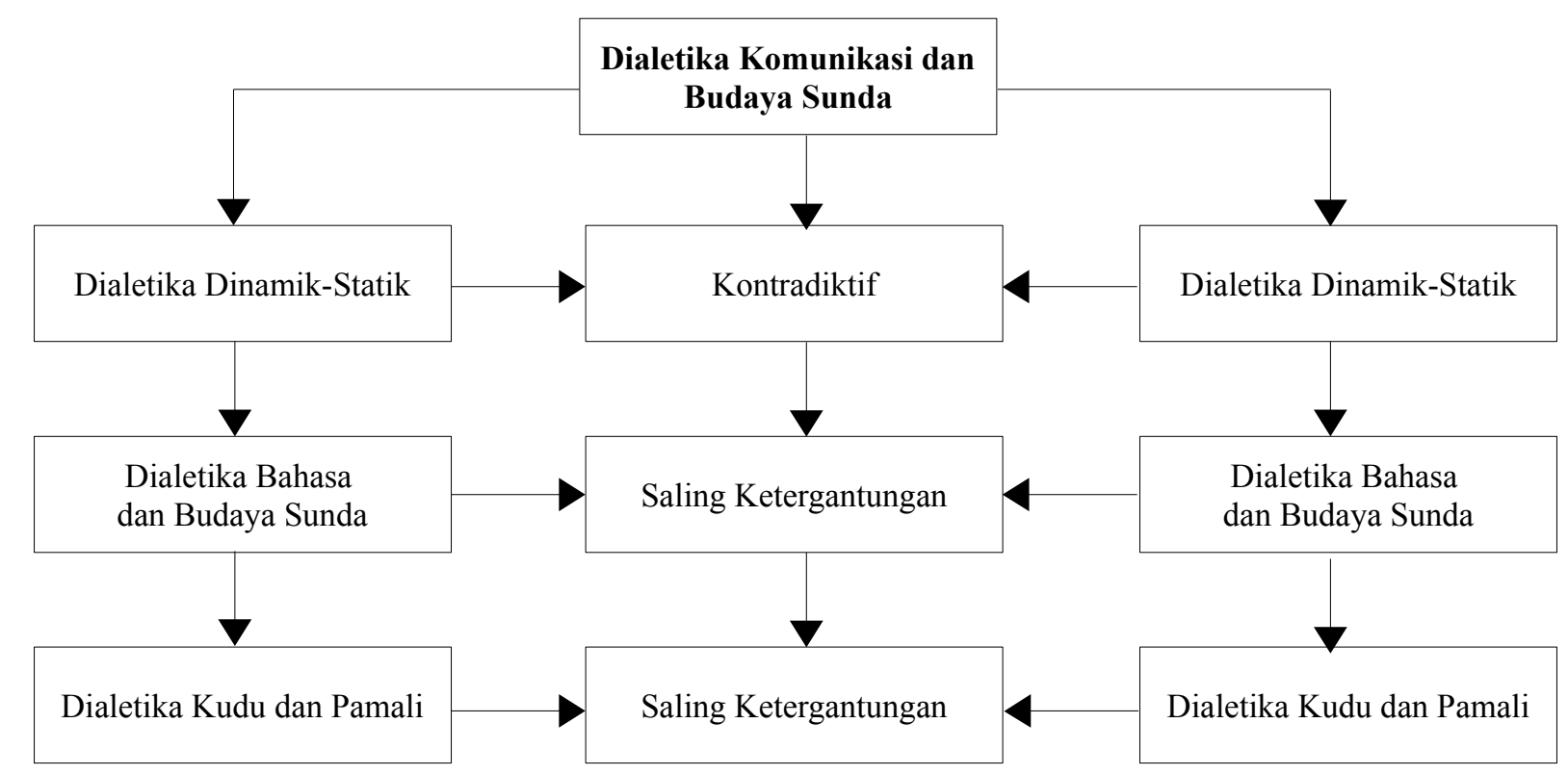

Sumber: Konstruksi Hasil Penelitian

Gambar 2

Model Dialektika Komunikasi dan Budaya Sunda 


\section{Dialektika Komunikasi dan Tradisi Islam}

Kemudian dialektika komunikasi dan tradisi Islam berlangsung dalam tiga pragmentasi yakni: 1) dialektika Pola Komunikasi dan Tradisi Islam; 2) dialektika Simbol Komunikasi dan Simbol Islam; 3) dialektika simbol verbal dan nonverbal; dan 4) dialektika Pesan Leluhur dan Pesan nilainilai Islam.

\section{Dialektika Pola Komunikasi dan Tradisi Islam}

Pada dialektika ini pola komunikasi yang diterapkan oleh masyarakat Kampung Dukuh adalah pola komunikasi vertikal dan horizontal. Pertama, pola komunikasi vertikal terdiri atas: (a) pola komunikasi ke atas, (b) pola komunikasi ke bawah. Pola komunikasi ke atas yaitu komunikasi yang dilakukan oleh warga kepada ketua adat Mama Uluk (kuncen) di saat upacara adat nyanggakeun (mempersilakan) dan manuj. Berdasarkan hasil wawancara, tanggal 8-9 Mei 2012, yang dimaksud upacara nyanggakeun adalah suatu kegiatan penyerahan sebagian hasil pertanian kepada kuncen untuk diberkahi. Masyarakat tidak diperbolehkan memakan hasil panennya sebelum melakukan kegiatan nyanggakeun. Sedangkan manuj upacara adat yang berbentuk penyerahan bahan makanan dari hasil bumi kepada kuncen untuk diberkahi pada hari raya Idulfitri dan Iduladha untuk perayaan atau syukuran. Pada upacara tersebut, bagaimana setiap warga yang datang ke rumah kuncen melakukan komunikasi antarpersonal, bisa secara diadik (antara seorang warga dengan sang ketua adat (kuncen), atau bisa juga secara triadik (antara dua atau tiga orang warga dengan ketua adat) untuk menyampaikan maksud dan tujuannya.

Sedangkan pola komunikasi ke bawah dilakukan ketika upacara adat setiap tanggal 14 Maulud setiap tahun dan upacara keagamaan. Pada upacara adat tanggal 14 Maulud setelah melaksanakan salat berjamaah di masjid, sang ketua adat (Mama Uluk) memberi wejangan (komunikasi) secara langsung satu arah (one way traffic communication) di rumah kuncen tentang berbagai hal Kampung Dukuh, mulai dari sejarah Kampung Dukuh sampai kepada nasihat-nasihat kehidupan untuk semua yang hadir baik warga pribumi Kampung Dukuh maupun para tamu wisatawan. Bentuk komunikasi yang diterapkan adalah bentuk komunikasi kelompok besar (large group communication). Setelah Sang kuncen (Mama Uluk) memberi tausiah dilanjutkan wasiat oleh seorang sesepuh, sebagaimana yang dijelaskan oleh Muhammad (2009) bahwa, "Sesudah wejangan yang diberikan oleh kuncen selesai, dilanjutkan ke acara wasiat disampaikan oleh sesepuh yang dianggap paling sepuh tentang kejadian zaman."

Kemudian pada acara keagamaan, seperti salawatan kamilah (memuji Rasul) yang dilakukan di rumah kuncen pada setiap hari Jumat. Dan upacara sebelasan (nama bilangan) yaitu upacara keagamamaan yang dilakukan setiap tanggal 11 dalam perhitungan bulan Islam dengan membaca merekah. Dalam upacara ini bagaimana seorang ketua adat memberikan tausiah atau nasihat kepada seluruh warga yang datang ke rumah kuncen. Komunikasi ini berlangsung satu arah (one way traffic communication) dari ketua adat kepada seluruh warga yang hadir. Karena sifatnya satu arah maka tampak monoton, sehingga konteks komunikasi berjalan secara alamiah dan tidak dinamis. Tetapi mereka khusus mendengarkan tausiah dari sang ketua adat dengan penuh ketawaduan dan kesederhanaan.

Pola komunikasi horizontal, terjadi antara warga yang satu dengan warga yang lainnya dalam kehidupan sehari-hari dan dalam acara-acara tertentu, seperti: acara pengajian, marhabaan, pernikahan, kelahiran, kematian dan upacara adat tanggal 14 Maulud setiap tahunnya. Dalam kehidupan sehari-hari mereka melakukan interaksi secara pribadipribadi (interpersonal communication), antara seseorang dengan orang lain (diadik) atau antara seseorang dengan dua/tiga orang (triadik). Interaksi di antara mereka tampak begitu akrab di setiap sisi kehidupan, baik ketika berada di rumah, di jalan, di kebun ketika bekerja maupun ketika salat berjamaah di masjid (buat kaum Adam) dan di rumah 
(buat kaum Hawa).

Demikianlah dialektika komunikasi dengan tradisi Islam sudah berlangsung lama, bagaimana komunikasi berkembang pada tradisi-tradisi keagamaan Islam, seperti pengajian, salawatan dan marhabaan. Pesanpesan komunikasi masuk ke setiap acara pengajian, salawatan, dan marhabaan, baik pesan yang verbal maupun nonverbal. Pesan verbal berbentuk kata-kata, ceramah, tausiah, bimbingan ibadah dan membaca Alquran yang disampaikan oleh ustaz dan ustazah kepada peserta pengajian dan anak-anak pengajian. Sementara pesan nonverbal berbentuk isyarat, gerakan, dan ekspresi wajah/tubuh ustaz ketika melakukan tausiah. Sebaliknya pengajian, salawatan, dan marhabaan bisa terus dilestarikan menjadi tradisi Kampung Adat Dukuh, karena peran komunikasi dan bahasanya. Bahasa komunikasi yang dipraktikkan adalah bahasa Sunda halus. Bahasa Sunda halus sudah menjadi karakteristik atau kebiasaan berbicara masyarakat Dukuh sehari-hari. Dalam konteks ini, Hymes dalam Ibrahim (1994) menjelaskan bahwa, etnografi berbicara menyangkut tentang situasi-situasi dan penggunaan pola dan fungsi berbicara sebagai suatu aktivitas tersendiri. Sebab, kajian Etnografi Komunikasi yang dimulai oleh Hymes, sejak awal memacu sejumlah studi tentang pola-pola komunikasi dalam berbagai masyarakat di seluruh dunia untuk dikembangkan.

Dialektika di atas, sebagai dialektika relasional yang totality, demikian menurut Baxter dan Montgomery (1996) artinya, mengakui adanya ketergantungan antara orang-orang yang berhubungan. Dengan demikian antara pola komunikasi dengan tradisi upacara keagamaan Islam, bersinergi secara dialektis. Pola komunikasi dengan bentuk-bentuk komunikasi seperti: komunikasi antarpersonal dan komunikasi kelompok sering dipraktikkan dalam upacara keagamaan seperti pengajian menjelang salat Jumat, membaca salawat kamilah setiap hari Jumat, dan membaca merekah setiap malam Jumat, serta pengajian Alquran di masjid.
Dialektika Simbol Komunikasi dan Simbol Islam

Dialektika simbol komunikasi dan simbol Islam pada masyarakat Adat Kampung Dukuh bersinergi satu dengan yang lainnya. Simbol komunikasi yang berbentuk verbal dan nonverbal. Simbol verbal berbentuk bahasa lisan dan tulisan, bahasa lisan berbentuk kata-kata, obrolan, ucapan, dan ceramah, sedang bahasa tulisan berbentuk surat dan transkrip-transkrip (tetapi bahasa tulisan jarang digunakan paling pada momentum tertentu yang dilakukan kuncen kepada pihak tertentu). Bahasa lisan yang dipraktikkan adalah bahasa Sunda yanga halus, seperti, kumaha damang (bagaimana kabarnya), dihaturan linggih di rorompok (ditunggu di rumah), ngahaturan tuang (mempersilakan makan), nyanggakeun (silakan), mangga tuang heula (mari makan dulu), linggih heula (mampir dulu), hatur nuhun (terima kasih), sawios (tidak apa-apa) dan lain-lain. Simbol-simbol ini dipraktikan oleh seluruh warga Kampung Dukuh, baik ketika dalam pergaulan hidup sehari-hari, maupun dalam upacara-upacara adat dan ritual keagamaan. Sedangkan simbol nonverbal berbentuk: gestur tubuh, gerakan tangan, gambar, benda-benda, dan lain-lain. Gerakan tubuh, anggukkan kepala biasa, biasa dilakukan oleh orang Dukuh di saat bertemu dengan orang lain apalagi kepada tamu yang datang dari luar, senyuman sering menghiasi masyarakat Dukuh dalam keseharian, dan lain-lain.

Kemudian simbol-simbol keislaman yang tetap eksis sampai saat ini relatif sangat banyak. Simbol keislaman juga, bisa berbentuk verbal atau nonverbal. Simbol verbal seperti ucapan, assalamualaikum warahmatullahi wabarakatuh bila bertemu di jalan dan pembuka di saat ceramah, ucapan innalillahiwainna ilaihi rajiun, bila ada yang mendengar kematian, astaghfirullahalazim, suara azan dan komat, membaca Alquran, doa-doa ketika acara nyanggakeun, tilu waktos, manuj, membaca salawat kamilah serta ritual-ritual keagamaan lainnya. 
Kemudian simbol Islam nonverbal terdiri atas: bangunan masjid, gambar bulan bintang, kaligrafi Alquran, dan lain-lain. Terdapat juga simbol tradisi Islam Sunda sekaligus menjadi tradisi Islam Kampung Dukuh yang berbentuk Bedug dan Kohkol (kentongan) yang dijadikan alat komunikasi warga Kampung Dukuh. Kohkol digunakan untuk memanggil masyarakat ketika akan melaksanakan salat, bahkan ada tiga waktu pemukulan kentingan, yaitu: pukulan yang pertama memberitahukan bahwa waktu salat sudah tiba, pukulan kedua jamaah yang mau salat berjamaah harus sudah kumpul di masjid, dan pukulan ketika salat akan dimulai.

Kedua simbol tersebut, saling menguatkan satu sama lain, simbol komunikasi memperkuat simbol-simbol Islam, dan simbol-simbol Islam dalam perpektif ilmu komunikasi sebagai bagian dari simbol komunikasi. Karena simbol komunikasi merambah ke semua dimensi kehidupan, baik dimensi politik, ekonomi, sosial budaya maupun dimensi kepercayaan dan agama termasuk kedalam agama Islam. Begitupula sebaliknya simbol-simbol Islam memperkaya khazanah ilmu komunikasi. Sebab ilmu komunikasi bisa berkembang karena jasa-jasa bidang lain yang mengukuhkan eksistensi ilmu komunikasi yang di dalamnya simbol-simbol komunikasi. Jadi dengan kata lain dialektika simbol komunikasi dan simbol Islam memiliki ketergantungan secara totality, sebagaimana yang dijelaskan oleh Baxter dan Montgomery (1996) dalam teorinya Dialektika Relasional, bahwa mengakui adanya saling ketergantungan antara orang-orang dalam sebuah hubungan (khusus) pada masyarakat Kampung Dukuh. Artinya masyarakat Kampung Dukuh tidak mempertentangkan simbol-simbol komunikasi bahasa Sunda dengan simbol-simbol keislaman dalam konteks kehidupan masyarakat Adat Dukuh sehari-hari. Bahkan masyarakat Adat Dukuh merasakan adanya keharmonisan simbolsimbol Islam dengan simbol-simbol bahasa dan komunikasi dalam berbagi dimensi kehidupan masyarakat Dukuh.

\section{Dialektika Pesan Leluhur dan Pesan Nilai- Nilai Islam}

Pesan para leluhur Adat Dukuh mengisyaratkan adanya kesungguhan mereka dalam menanamkan pesan moral yang harus ditaati oleh generasi berikutnya. Pesan moral tersebut teridiri atas perintah dan larangan. Perintah adalah sesuatu yang $k u d u$ (harus) dilaksanakan oleh anak cucu Embah Dukuh, terutama adat istiadat yang biasa dilakukan sesepuh terdahulu, seperti: upacara ngahaturan tuang, tilu waktos, manuj, moros, cebor opat puluh, jaroh, salawatan, dan sebelasan. Sedangkan larangan atau Pamali, sebagaimana yang telah dijelaskan di atas.

Pesan moral leluhur tersebut, bila dilihat dalam perspektif Islam ada yang relevan dan ada juga yang bertentangan dengan ajaran Islam. Adat istiadat yang relevan, seperti: salawatan kamilah (memuji Rasul Muhammad) dan jaroh (berziarah ke makam Syekh Abdul Jalil). Membaca salawat memang diajarkan dalam Islam, sebagaimana difirmankan oleh Allah dalam Alquran, berbunyi, artinya: "Sesungguhnya Allah dan para malaikat-Nya bersalawat untuk Nabi. Wahai orang-orang yang beriman, bersalawatlah kamu kepada Nabi dan ucapkanlah salam dengan penuh penghormatan kepadanya." (QS. 33:56).

Dan ziarah juga diperintahkan di dalam Islam, sesuai sabda Nabi SAW:

Diriwayatkan dari Abu Hurairah r.a. ia berkata: Nabi SAW pernah berziarah ke kubur ibunya, lalu beliau menangis sehingga orang-orang yang di sekelilingnya turut menangis, kemudian beliau bersabda, "Aku mohon izin kepada Tuhanku untuk memohonkan ampunan bagi ibuku, namun tidak diperkenankan, dan aku mohon izin kepada-Nya untuk berziarah ke kubur ibuku. Lalu aku perkenankan maka berziarahlah ke kubur, karena kubur itu bisa mengingatkan kematian. (H.R. Muslim, bab 45).

Namun, jaroh yang dipraktikkan oleh masyarakat adat Kampung Dukuh berbeda dengan ziarah dalam Islam. Mereka melakukan jaroh ke makam Syekh Abdul Jalil yang sebelumnya mengambil cebor empat puluh dan mengambil air wudu serta 
menanggalkan semua perhiasan serta menggunakan pakaian yang tidak bercorak. Padahal di dalam ajaran Islam ziarah diperbolehkan selama tidak mengandung unsur syirik (menduakan Allah) dengan tujuan hanya mendoakan kepada orang yang telah wafat lebih dulu. Begitupula di dalam ajaran Islam tidak ada persyaratan-persyaratan khusus seperti yang berlaku di masyarakat Kampung Dukuh.

Demikian pula Pamali ada yang selaras dengan syariat Islam dan ada pula yang bertentangan dengan nilai-nilai ajaran Islam. Pamali yang selaras dengan ajaran Islam adalah (a) tidak boleh kencing sambil berdiri, (b) dilarang makan sambil berdiri, (c) dilarang melanggar syara (syariat Islam atau hukum Islam), dan tidak boleh menikah dengan orang non muslim. Pertama, dilarang makan dan kencing sambil berdiri, memang dilarang dalam Islam, didasarkan kepada hadits yang berbunyi:"Janganlah kamu minum dan makan sambil berdiri." (Hadits). Kedua, dilarang melanggar syara atau syariat Islam, seperti mencuri, membunuh, minuman keras, berzinah, menyakiti kedua orang tua, dan lain-lain. Sebab banyak sekali di dalam Alquran dan Alhadis yang menyatakan demikian, di antaranya: "Laki-laki yang mencuri dan perempuan yang mencuri, potonglah tangan keduanya (sebagai) pembalasan bagi apa yang mereka kerjakan dan sebagai siksaan dari Allah, dan Allah Maha Perkasa lagi Maha Bijaksana."(Q.S. AlMaidah ayat 38). Kemudian larangan berzinah, Allah berfirman: “...dan janganlah kamu mendekati zina; Sesungguhnya zina itu adalah suatu perbuatan yang keji. dan suatu jalan yang buruk." (Q.S. 17:32). Lalu larangan meminum minuman keras dan berjudi, sebagaimana ditegaskan dalam Alquran, berbunyi: "Wahai orang-orang yang beriman! Sesungguhnya minuman keras, berjudi (berkurban untuk) berhala, dan mengundi nasib dengan anak panah adalah perbuatan keji dan termasuk perbuatan setan. Maka jauhilah (perbuatan-perbuatan) itu agar kamu beruntung."

Ketiga, dilarang menikah dengan orang non Islam, jelas Allah mensinyalir di dalam Alquran, yang berbunyi: "dan janganlah kamu menikahi wanita-wanita musyrik, sebelum mereka beriman. Sesungguhnya wanita budak yang mukmin lebih baik dari wanita musyrik, walaupun Dia menarik hatimu dan janganlah kamu menikahkan orang-orang musyrik (dengan wanita-wanita mukmin) sebelum mereka beriman..."(Q.S. 2:221).

Sedang Pamali yang bertentangan atau tidak ada dasarnya di dalam ajaran Islam relatif sangat banyak, misalnya: dilarang menumbuk padi hari Jumat, dilarang bepergian pada saat larangan sasih atau kala ageung, dilarang melakukan kegiatan apapun pada hari naas, tidak boleh memasuki makam keramat pada sembarang waktu, dan lainlain. Semua larangan itu, sesungguhnya bertentangan dengan ajaran Islam, karena Islam tidak mengajarkan kepada kita tentang hari-hari baik dan hari-hari naas, semua hari di dalam perspektif Islam semuanya baik, kecuali hari-hari itu digunakan untuk perbuatan maksiat. Dengan demikian larangan-larangan tersebut, sebagai pepatah para leluhur yang didasarkan para rayu atau akal para leluhur terdahulu dan tidak didasarkan pada nilai-nilai syari (ajaran Islam). Oleh karena itu, dalam perspektif teori Dialektika Relasional dari Baxter dan Barbara (1996) bahwa dialektika yang berlangsung adalah dialektika kontradiksi yaitu dua elemen yang kontradiksi (antara pesan moral para leluhur dengan pesan nilainilai ajaran Islam).

Kemudian Pamali lain yang berkenaan dengan: tidak boleh menjulurkan kaki ke arah makam keramat, tidak boleh makan menggunakan sendok dan garpu, tidak boleh memiliki benda-benda elektronik seperti televisi, radio, tape recorder, dan lain-lain. Tidak boleh menggunakan petromak atau jenis lampu lain yang menggunakan minyak tanah, dan tidak boleh memiliki kursi, lemari, ranjang, perhiasan dan peralatan lain yang terkesan mewah. Hal ini dapat dipahami sebagai sikap dan perilaku untuk menunjukkan kesederhaan dan ketawaduan masyarakat Kampung Dukuh, jauh dari kesan mewah dan glamor seperti yang sering ditunjukkan orang-orang kota. Kesederhanaan dan ketawaduan masyarakat Dukuh sebagai 


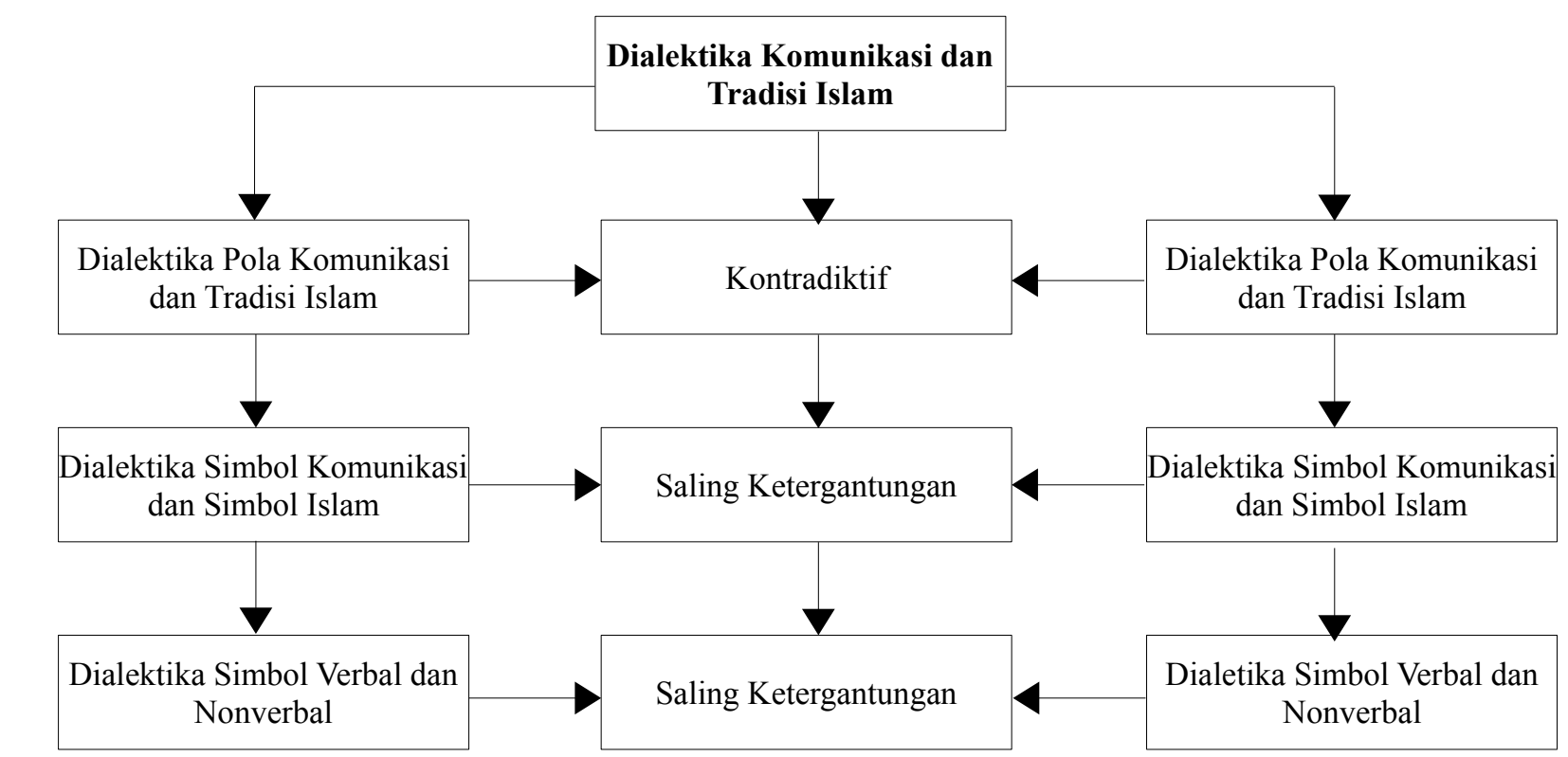

Sumber: Konstruksi Hasil Penelitian

\section{Gambar 3 \\ Model Dialektika Komunikasi dan Tradisi Islam}

bentuk implementasi ajaran Islam dengan menganut paham tasawuf. Tasawuf yang dipraktikkan oleh masyarakat Dukuh dengan pendekatan paham tarekat naqsabandiyah. Hal ini tampak pada ritual keagamaan adat Dukuh yang sering membaca merekah atau marhabaan. Paparan di atas, dapat digambarkan sebagaimana model pada gambar 3.

\section{Dialektika Tradisi Islam dan Budaya Sunda}

Selanjutnya dialektika Tradisi Islam dan budaya Sunda terjadi pada beberapa tingkatan, yaitu: (1) dialektika Nilai Islam dan Norma Budaya, (2) dialektika Aqidah Islam dan Mitos-mitos.

\section{Dialektika Nilai Islam dan Norma Budaya}

Persentuhan nilai Islam dan budaya Sunda sudah berlangsung sejak ratusan tahun yang lalu termasuk yang terjadi di Kampung Dukuh. Nilai-nilai Islam sangat kuat terasa pada sikap dan perilaku kehidupan masyarakat Kampung Dukuh sehari-hari. Fenomena tersebut, dapat dilihat pada ritual keagamaan mereka, misalnya, ketika datang panggilan salat wajib: Zuhur, Asar, Magrib, Isya, dan Subuh, mereka ramai datang ke masjid untuk mengikuti salat berjamaah. Setelah selesai mengikuti salat berjamaah, anak-anak laki-laki dan perempuan langsung belajar mengaji Alquran di bawah bimbingan ustaz dan ustazah setempat. Mereka belajar mengaji tidak hanya bada salat magrib sebagaimana kebiasaan masyarakat Sunda pada umumnya, tetapi mereka mengaji setiap bada Zuhur, Magrib dan bada Subuh. Kemudian ketika bulan suci Ramadan tiba, masyarakat juga menyambut kedatangan bulan suci tersebut dengan sukacita dengan mempersiapkan diri untuk melaksanakan ibadah puasa.

Di samping itu semarak keagamaan di Kampung Dukuh, juga terlihat pada hari-hari besar Islam, seperti Hari Raya Idulfitri 1 Syawal, Hari Raya Iduladha 10 Rayagung, 12 Maulud, 27 Rajab peringatan Isra Miraj, dan lain-lain. Pada hari-hari penting tersebut, masyarakat Kampung Dukuh sangat antusias untuk mengadakan berbagai acara demi menghormati hari-hari besar tersebut. Upacara keagamaan, seperti salat Idulfitri, 
Iduladha, dan peringatan Maulud Nabi dan 10 Muharam, dipadukan dengan upacara adat Tilu Waktos (tiga waktu) yaitu pada waktuwaktu tersebut, sang kuncen membawa makanan ke dalam Bumi Alit (Bumi dalam) atau Bumi Lebet (Rumah dalam) untuk membaca tawasul (berdoa). Lalu ritual keagamaan lain yang rutin dilaksanakan oleh masyarakat adat Kampung Dukuh adalah pelaksanaan salawatan kamilah (memuji Rasul) dan sebelasan. salawatan kamilah dilaksanakan pada setiap hari Jumat di rumah kuncen dengan membaca salawat sebanyak 4.444 kali yang dihitung dengan menggunakan batu. Dan upacara sebelasan yaitu upacara Adat Dukuh dengan membaca merekah setiap tanggal 11 bulan Islam.

Kolaborasi nilai-nilai Islam dengan norma-norma budaya Dukuh, merupakan ritual yang "mutualis simbiosis" yang saling melengkapi. Dalam konteks ini terjadi dialektika totality sebagaimana konsep (Baxter dan Barbara, 1996) dalam teori Dialektika Relasional yaitu adanya saling ketergantungan antara orang-orang yang saling berhubungan. Suasana masyarakat Kampung Dukuh sangat menyenangi kolaborasi implementasi nilai-nilai Islam dengan norma-norma Adat Dukuh. Karena budaya tersebut telah dipraktikkan oleh para leluhur Kampung Dukuh berabad-abad. Jadi sudah sangat melembaga dalam kehidupan masyarakat Kampung Dukuh.

Begitupula cara berpakaian masyarakat Adat Dukuh relatif sangat Islami, baik lakilaki maupun perempuannya. Laki-lakinya biasa menggunakan peci dan sarung sebagai pakaian adat masyarakat Islam Sunda, dan pakaian perempuannya menutup aurat dengan memakai jilbab. Pakaian ini digunakan oleh mereka dalam setiap kesempatan, baik dalam ritual keagamaan, upacara adat maupun dalam kehidupan sehari-hari mereka. Dalam fenomena tersebut, telah terjadi pula dialektika totality, bagaimana implementasi nilai-nilai Islam tentang kewajiban menutup aurat (QS.33:59) dengan pakaian adat kebaya, sarung, dan peci menyatu saling menguatkan, bahkan telah menjadi tradisi masyarakat Dukuh sejak ratusan tahun yang lalu sampai hari ini.

\section{Dialektika Aqidah Islam dan Mitos-Mitos}

Dialektika aqidah Islam dengan mitosmitos masyarakat Adat Kampung Dukuh telah berlangsung lama seperti dimensi-dimensi lainnya. Islam mengajarkan kepada umatnya untuk bersikap dan berperilaku sesuai dengan tuntunan Alquran dan Sunnah termasuk dalam hal aqidah (kepercayaan). Di dalam Islam bahwa Tuhan itu adalah satu Yang Maha Esa, "Kul huwawllahu ahad" (QS. 112:1) "katakanlah bahwa Allah itu Tuhan Yang Maha Esa". Allahlah tempat memohon dan bergantung, "Hanya kepada kepada-Mu (Allah) kami menyembah dan hanya kepadaMu kami memohon pertolongan." (QS. 1:5). Masyarakat Dukuh sangat memahami hal tersebut, bahwa Tuhan mereka adalah Tuhan Yang Maha Esa, "Allah", Tuhan tempat meminta, dan Tuhan Yang Maha Kuasa. Namun implementasinya kadang campur aduk, di satu sisi mereka mempercayai Tuhan Allah tempat mengadukan nasib dan bergantung, tetapi di sisi lain mereka juga percaya terhadap mitos-mitos nenek moyang mereka, misalnya adanya makam yang dianggap keramat yaitu makam Syekh Abdul Jalil (pendiri Kampung Dukuh), makam Eyang Dukuh (Pengikut Syekh Abdul Jalil), dan makam Eyang Hasan Husen (keturunan Embah Dukuh).

Menurut kepercayaan mereka bahwa makam-makam leluhur tersebut dianggap suci dan dapat memberikan efek magis kepada orang yang menghormatinya, dan orangorang menyepelekannya akan berakibat malapetaka. Maka mendatangi (jaroh) makan keramat di atas, tidak sembarang orang dan tidak boleh sembarang waktu. Misalnya, Pegawai Negeri Sipil (PNS) dilarang ziarah karena menurut mitos mereka, apabila seorang PNS melakukan ziarah ke makam keramat tersebut akan mengalami musibah. Begitupula perempuan yang haid tidak boleh ziarah, karena ziarah harus dalam keadaan suci. Demikian pula waktu yang digunakan tidak boleh sembarang waktu, harus hari Sabtu, kalau ini dilanggar maka akan mendatangkan malapetaka.

Mitos lain yang menjadi kepercayaan masyarakat Adat Dukuh adalah: tidak boleh 
menjulurkan kaki ke arah makam keramat baik pada waktu tidur ataupun sedang duduk; tidak boleh buang air kecil atau besar ke arah makam kecuali dilakukan di jamban umum; tidak boleh menumbuk padi pada hari Selasa atau Jumat; tidak boleh bepergian pada larangan sasih atau kala ageung; tidak boleh bepergian pada hari naas, dan tidak boleh melangkahi padi (nyi Sri), dan lain-lain.

Mitos-mitos tersebut sudah menjadi hukum adat yang harus dilakukan oleh seluruh warga Kampung Dukuh. Kalau ada warga yang melanggar akan berdampak negatif pada pribadi-pribadi pelanggar dan seluruh warga Kampung Dukuh. Oleh karena itu, mereka sangat patuh terhadap kepercayaan tersebut, karena itulah elmu Dukuh yang diwariskan oleh nenek moyang mereka buat bekal generasi berikutnya sampai saat ini.

Dengan demikian, dialektika yang terjadi antara aqidah Islam dengan mitosmitos warga Kampung Dukuh adalah, Dilalektika Kontradiksi (Contradiction Dialectic) artinya merujuk pada oposisi - dua elemen yang saling bertentangan. Di sisi lain Islam mengajarkan bahwa semua orang yang sudah wafat adalah kedudukannya sama, dan makam yang satu dengan yang lain sama pula, sedangkan mitos Dukuh mengajarkan bahwa ada makam yang dianggap keramat atau diagungkan. Begitupula Islam menekankan bahwa semua hari-hari itu baik, tetapi Adat Dukuh mempercayai adanya harihari naas. Selanjutnya ziarah dalam perspektif Islam dalam kerangka mendoakan orang yang sudah wafat dan tidak meminta sesuatu kepada arwah yang sudah meninggal dunia serta pelaksanaan ziarahnya cukup simpel.

Sedangkan jaroh (ziarah) menurut kepercayaan Adat Dukuh boleh mengharapkan sesuatu dari makam keramat tersebut. Kemudian tata cara ziarahnyapun memilik kekhususan, misalnya:

1. Berziarah hanya bisa dilakukan pada hari Sabtu, selain itu tidak bisa dilakukan;

2. Sebelum melakukan ziarah, harus mandi terlebih dahulu, kemudian berwudu dengan menggunakan air doa;

3. Tidak boleh memakai pakaian dalam saat berziarah, baik laki-laki maupun perempuan. Pakaian laki-laki memakai sarung dan baju koko yang tidak bermotif serta memakai peci. Sedangkan perempuannya memakai samping dan pakaian biasa;

4. Tidak boleh memakai alas kaki ketika masuk area pemakaman;

5. Tidak boleh meludah di area pemakaman;

6. Ada ritual ketika menuju ke area pemakaman yaitu peziarah berhenti selama 8 kali di tempat yang berbeda, diselingi doa yang dipimpin oleh kuncen, dan pada pemberhentian ke empat diselingi dengan pencucian kaki oleh air yang telah disediakan;

7. Dan masuk ke makam keramat antara laki-laki dan perempuan tempatnya berbeda serta jaraknya tidak boleh terlalu dekat.

Model ziarah tersebut, dapat dipahami bahwa di satu sisi, si peziarah harus dalam keadaan suci, baik dari hadats kecil maupun besar, sopan, dan tertib. Hal ini sangat positif karena ziarah sesuatu yang baik, maka alangkah lebih bagus pezirahnyapun dalam keadaan suci. Namun di sisi lain apabila ziarah ke makam keramat terebut, ada harapan ingin usahanya sukses, berhasil dan cepat dapat jodoh, misalnya, maka hal tersebut termasuk syirik, dan syirik dilarang di dalam Islam. Sebagaimana difirmankan oleh Allah SWT. Yang berbunyi: "Sesungguhnya Allah tidak akan mengampuni dosa karena mempersekutukanNya (syirik), dan Dia mengampuni dosa selain (syirik) itu bagi siapa yang dikehendaki. Barangsiapa mempersekutukan Allah, maka sungguh dia telah berbuat dosa yang besar" (QS.4:48). Dengan demikian dialektika antara syariat Islam dengan mitosmitos masyarakat Kampung Dukuh selalu kontradiksi atau bertentangan satu sama lain. Berdasarkan penjelasan di atas, dialektika komunikasi dan budaya Sunda dapat diilustrasikan seperti pada gambar 4 . 


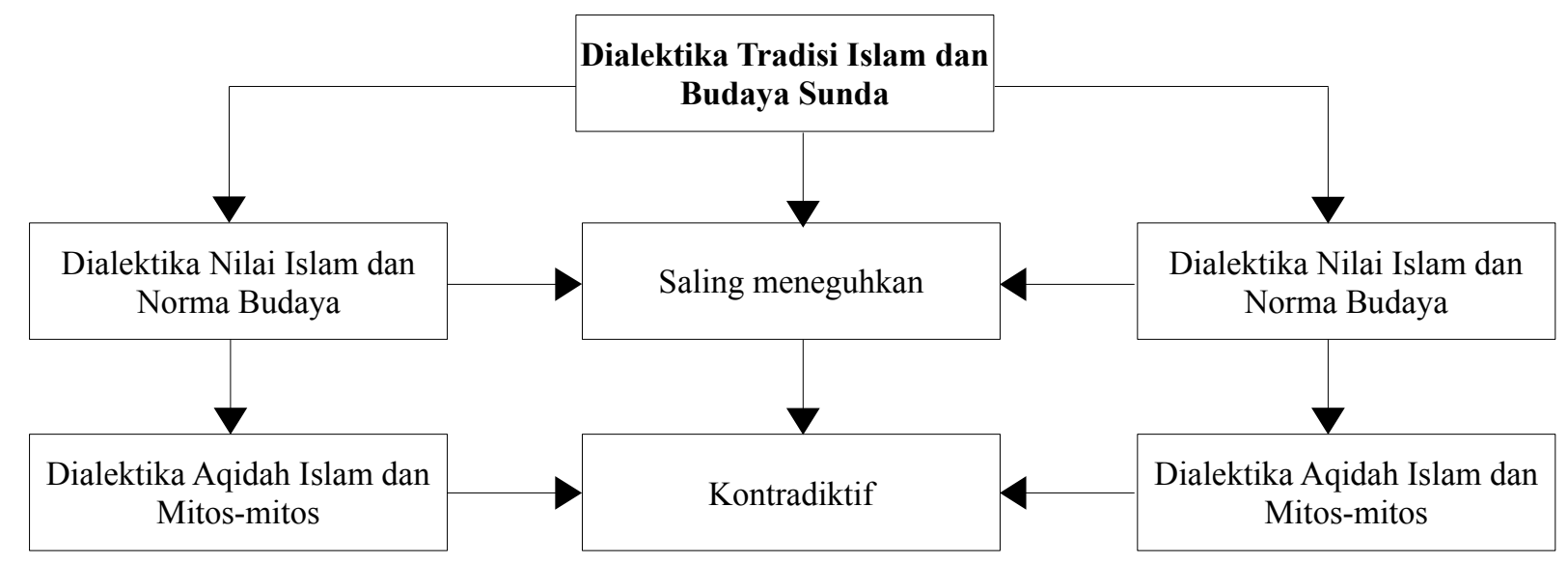

Sumber: Konstruksi Hasil Penelitian

\section{Gambar 4 \\ Model Tradisi Islam dan Budaya Sunda}

\section{PENUTUP}

\section{Simpulan}

Dialektika komunikasi dan budaya terjadi dalam tiga tingkatan, yaitu (1) dialektika dinamis-statis, (2) dialektika bahasa dan budaya Sunda, dan (3) dialektika keharusan dan Pamali. Dialektika dinamikstatik terjadi antara kelompok sesepuh dan generasi muda Kampung Dukuh berlangsung secara kontrakdiktif. Kemudian dialektika antara bahasa dan budaya Sunda berlangsung secara dialektis totality atau saling ketergantungan satu sama lain. Sedangkan dialektika antara $k u d u$ (keharusan) dan Pamali terjadi juga secara totality saling bersinggungan.

Dialektika komunikasi dan tradisi Islam berlangsung dalam tiga pragmentasi yaitu (1) Dialektika pola komunikasi dan tradisi Islam, (2) Dialektika simbol komunikasi dan simbol Islam, dan (3) Dialektika simbol verbal dan simbol nonverbal. Dialektika pola komunikasi dan tradisi Islam berjalan secara sinergis satu dengan lainnya saling membutuhkan dan ketergantungan. Selanjutnya dialektika simbol komunikasi dan simbol Islam berlangsung secara dialektis totality artinya memiliki ketergantungan satu sama lain. Demikian pula dialektika simbol verbal dan nonverbal juga berjalan secara sinergis saling ketergantungan dalam suasana hubungan yang harmonis.
Dialektika tradisi Islam dan Budaya Sunda terpolarisasi dalam dua tingkatan yakni: (1) dialektika nilai Islam dan norma budaya, dan (2) dialektika aqidah Islam dan mitos-mitos. Dialektika nilai Islam dan norma budaya berlangsung secara dialektika totality saling menguatkan dan saling meneguhkan satu dengan yang lainnya. Sedangkan dialektika aqidah Islam dan mitos-mitos berlangsung secara kontradiktif, artinya merujuk pada oposisi yang saling bertentangan. Di satu sisi aqidah Islam menekankan kepada masyarakat Kampung Dukuh untuk konsisten mengimani Allah Yang Maha Esa tanpa unsur syirik, tetapi di sisi yang lain mitos-mitos peninggalan nenek moyang mengandung unsur syirik atau menduakan Tuhan/Allah.

\section{Saran}

Studi tentang komunikasi lintas budaya tidak pernah dari informasi-informasi yang aktual dan fenomena-fenomena yang dinamis. Karena perkembangan suatu budaya pada etnis-etnis atau entitas tertentu dari waktu ke waktu selalu berubah. Oleh karena itu, penelitian sejenis perlu terus dilakukan tidak hanya melalui pendekatan etnografi, tetapi bisa melalui pendekatan fenomenologis dan etnometodologi. Kemudian khusus untuk Pemerintah Daerah Kabupaten Garut khususnya dan pemerintah daerah Provinsi 
Jawa Barat umumnya, diharapkan dapat melakukan pembinaan secara intensif dan pengelolaan secara serius tentang pelestarian budaya lokal, sehingga pada gilirannya Adat Kampung Dukuh menjadi objek wisata yang memiliki daya tarik tinggi. Di samping itu juga, Pemerintah Daerah Kabupaten Garut diharapkan dapat melakukan pembinaan ekonomi kreatif mikro yang berbasis kearifan lokal bagi masyarakat Adat Kampung Dukuh sehingga kesejahteraan mereka meningkat.

\section{DAFTAR PUSTAKA}

\section{Buku:}

Al-Qur 'anul Karim. (1431 H). Miracle The Reference. Bandung: Sygma Publishing.

Ambary, Hasan Muarif dan Madjid, Nurcholis, dkk. (1999). Ensiklopedia Islam 2. Jakarta: PT Ichtiar Baru Van Hoeve.

Ekajati, Edi S. (1984). Masyarakat Sunda dan Kebudayaannya. Jakarta: Giri Mukti Pasaka.

Gorys Keraf. (1997). Tata Bahasa Indonesia. Jakarta: Gramedia.

Ibrahim, Abd Syukur. (1994). Panduan Penelitian Etnografi Komunikasi. Surabaya: Usaha Nasional.

Koentjaraningrat. (2009). Pengantar Ilmu Antropologi. Jakarta:Rineka Cipta.

Kuswarno, Engkus. (2008). Metode Penelitian Komunikasi: Etnografi Komunikasi. Bandung: Widya Padjadjaran.

Mulyana, Deddy. (2003). Metodologi Penelitian Kualitatif - Paradigma Baru Ilmu Komunikasi dan Ilmu Sosial lainnnya. Bandung:Remaja Rosdakarya.

Muyana, Deddy dan Solatun. (2007). Metode
Penelitian

Komunikasi.

Bandung:Remaja Rosdakarya.

Rosidi, Rosidi. (2010). Masa Depan Budaya Daerah. Jakarta: Pustaka Jaya.

Thomas R. Lindlof dan Bryan C. Taylor. (2002). Qualitative Communication Research Methods. California: Sage Publication.

\section{Sumber lainnya: \\ Jurnal:}

Hidayat, A. (2008). Lintas Budaya. Jurnal Sosial dan Humaniora, Vol. 4 No.1.

\section{Disertasi:}

Sugito, Toto. (2010). Dialektika Komunikasi dan Budaya. Disertasi,Universitas Pajdadjaran.

\section{Internet:}

Adriyanto, Krisna. (2010). Teori Komunikasi Dialektika Relasional.Tersedia dalam $<$ http://mysteriouxboyz90.com/2010/08 /teori-komunikasi-dialektikarelasional.html>.Diakses tanggal $4 \mathrm{Mei}$ 2013.

Komar. H. Daud Muhammad. (2009). Pamali/Pantangan dalam Adat Kampung Dukuh. tersedia dalam $\leq$ www.suaramerdeka.com $>$ diakses tanggal 4 Mei 2013.

Susanto,Eko. (2013). Kampung Adat Dukuh. Tersedia dalam $<$ Www. Hotelgarut.net/201302/Kampung-Adatdukuh-cikelt.html $>$ diakses tanggal 4 Mei 2013. 